\title{
Learning power globally?
}

\author{
Wiel Veugelers
}

Received: 11 January 2007 / Accepted: 11 January 2007 / Published online: 17 March 2007

(C) Springer Science+Business Media B.V. 2007

The work of Jeannie Oakes and her colleagues at the Institute for Democracy, Education and Access (IDEA) at the University of California Los Angeles (UCLA) has been characterised during the last 10 years by strong connections between academic work and social action in supporting disenfranchised groups that try to improve education, promote equity politics and change the world. This work has been documented in many articles and shared with the educational and academic community on conferences (see for example Oakes \& Lipton, 1999; Oakes, Quartz, Ryan, \& Lipton, 2000).

Learning Power brings all these initiatives together in a coherent framework. It reads like a journey into a part of American social, political and educational reality that is not visible in the European media. It shows that in the US some people really work on democracy, not as a formal institution but as a way of life. The book illustrates in great detail how researchers, teachers and students at IDEA work on educational change. In these presentations and analyses they demonstrate and develop new views on important concepts of educational change. They clearly show that educational change is a social and political activity and that educational change theorists should incorporate explicit political processes in their concepts. They also show that by making political choices in their practical and theoretical work, the level of working and understanding is deepened. The practice and theory they present is far removed from a technical rationality that is so dominant in many works on educational change. Instead of saying that the social and political context is part of the reality they make it part of change processes and their theoretical framework itself. For example, while many American publications on educational change argue that education should connect to the community, this is often presented as a general and mechanical connection. Oakes and Rogers show that the community is a

W. Veugelers $(\square)$

University of Amsterdam, Amsterdam, The Netherlands

e-mail: W.M.M.H.Veugelers@uva.nl

W. Veugelers

University for Humanistics, Utrecht, The Netherlands 
complicated social and political arena that reflects and manifests power relations. They choose to empower the underprivileged to create more equality, greater access and participatory democracy.

In Learning Power many transformational educational activities-described as "research design experiments"-are presented. For example, teacher education at UCLA focuses on education for underprivileged youth in urban schools. These schools in particular need strong and qualified teachers that understand how to take social action. Educational research as conceptualized by Oakes and Rogers sees inquiry as a habit of mind that must be acquired by all participants to develop radical educational processes for changing the world. They do not investigate educational change only from outside and on one particular issue, but instead conceive it as a social and cultural process in which structures and agency reciprocally shape practices and discourses.

Learning Power shows the deep social, cultural and racial processes of inequality and possibilities for collaborative work among social activists, educational workers and educational researchers. According to the philosophy of Oakes and Rogers these functions are not separated between different groups with their own organizations. Rather, the scholars and activists of IDEA combine social action, education and research into a rich ensemble of interconnected practices.

Having made all these favourable assessments of the work of the IDEA, I now want to make six further reflections from the vantage point of Western Europe.

\section{Learning power transcends technical rationality}

Outside of the US we are confronted with many American educational consultants who have (according to themselves) very good and successful programmes for school development, professional development, educational change, critical thinking, cooperative learning, and so forth. They travel extensively and present their solutions to the rest of the world. One paradox of this activity is that they present their programmes in, for example, Western Europe and Asian countries that are for more successful on educational standards than the US. I have sometimes questioned these educational consultants about why American education in general does not do so well in international studies. They mostly answer, with a smile, that not all American schools follow their program. They then just go on with promoting their product. Contrary to these American educational consultants the work of Oakes and Rogers does not focus on realizing middle-class social competencies but on changing social and political attitudes, empowering people, enlarging their social-political knowledge and their competences and willingness to take social action. Their analysis is embedded in the local, the social and the political. They do not offer fixed programmes but instead provide examples of educational change and theoretical concepts that can help other people to describe, analyse and change their own practices.

In different parts of the non-western world we see grassroots initiatives of academic scholars and social activists that try to combine educational change and social action. These people, as I have experienced on several occasions, are confronted with many educational change programmes developed by Americans that reduce their possibilities for analysing and changing education in a more social and political 
way. Learning Power shows in the US itself social critique and social change are necessary and possible. Learning Power transcends the technical-rational and shows that educational change is not a prefab product.

\section{Involvement and distance}

One of the strengths of this book for readers, including those without advanced training in education, is that it is really reveals a compelling inside story. Activities and research are situated in real social contradictions, and are elaborated upon from the perspective of empowering the underprivileged. This positioning makes the picture and the analysis strong. However, sometimes I also felt the need to have some more distance, to present more clearly different views, and to reflect more "on action" then "in action". It would be challenging to write books like this that alternate more inside and more outside positions. Another suggestion to make the work even more thoughtful would be to do more research on dialogues within and among groups. This could show different perspectives in a group and how personal and collective meanings develop in dialogical processes in and among groups.

\section{Dewey forever}

The book is part of the John Dewey lecture series and this can be an argument for making so many references to John Dewey. Giving so much credit to Dewey is not uncommon in American educational publications. According to his followers, it often seems that John Dewey addressed nearly every important idea on education. This raises the following question: given these great ideas, why is it that American education still needs so much change? Comparing the work of Dewey with the work presented in this book, it seems that Oakes and her colleagues make Dewey more social-political and more transformational than he perhaps did himself.

\section{Personal development and social movements}

Is it time to question whether Dewey's greatness is overstated? Giving so much attention to the person Dewey underestimates the social movements and the broader historical context that Dewey was part of. It results in personalising a social movement. I experienced a similar problem in reading Learning Power. The social movement described is really a flexible network with no real formal organization-not even having a clear name. As a consequence of publishing about it, it appears that Oakes, Rogers, and their colleagues connect their names to the actions. In reviewing the book, I experienced the danger is of celebrating the writers more than the movement. We should try to avoid personalising social movements into big individual heroes. 


\section{Autonomy and control}

In many western European countries educational policy is more centralised than in the US: there is a stronger national curriculum, the inspectorate controls a lot, and regulations for the teaching profession are stricter. This top-down control makes equality between schools greater then in a more market-oriented system like in the US. The recent trend in the Netherlands and other Western European countries to enlarge autonomy creates more diversity between schools in regard to the pedagogical goals directed toward student populations (Veugelers, 2007). School choice creates even more diversity in student population between schools. Paradoxically, a strongly centralised educational policy like we use to have provides fewer possibilities for grassroots educational change initiatives like those described in Learning Power than in a more market oriented educational policy.

\section{Networking}

In many educational change theories networking of schools is promoting (Veugelers \& O'Hair, 2005). In networks schools can work together with other schools and community groups. Learning Power is a great example of all kind of connections, flexible structures, the empowerment of participants, and bottom-up initiatives. On the whole, it gives a great overview of intensive networking without falling into the trap of prescribing an easy model others should seek to apply directly to their situations.

To conclude, Learning Power is well contextualised in American educational and political practice. By combining theory and practice and research and social action the book is interesting for educators outside the USA as well. The book does not gives one a well-defined programme but through its critical engagement, analysis and action it stimulates reflection on one's educational and political practices and provides valuable tools to help one to get involved directly in social action.

\section{References}

Oakes, J., \& Lipton, M. (1999). Teaching to change the world. Boston: McGraw Hill College.

Oakes, J., Quartz, K.H., Ryan, S., \& Lipton M. (2000). Becoming good American schools. San Francisco: Jossey-Bass.

Veugelers, W. (2007). Creating critical-democratic citizenship education: empowering humanity and democracy in Dutch education. Compare, 37(1), 95-109.

Veugelers, W., \& O' Hair M. J. (Eds.) (2005). Network learning for educational change. Maidenhead: Open University Press. 